\title{
HUBUNGAN TINGKAT PENDIDIKAN DAN PENGETAHUAN IBU TENTANG GIZI DENGAN TINGKAT KEHADIRAN BALITA DI POSYANDU KELURAHAN TEGALGEDE KECAMATAN SUMBERSARI KABUPATEN JEMBER
}

\author{
Oleh: \\ ADHININGSIH YULIANTI *)
}

\begin{abstract}
ABSTRAK
Usaha Perbaikan Gizi Keluarga merupakan salah satu upaya untuk meningkatkan keadaan gizi masyarakat, yang sebagian kegiatannya dilaksanakan di posyandu.Hal ini secara tidak langsung dipengaruhi oleh pendidikan dan pengetahuan. Pengetahuan ibu tentang gizi sangat penting, karena yang menentukan menu makanan sehari-hari adalah seorang ibu. Dengan pendidikan dan pengetahuan yang dimilikinya diharapkan seorang ibu balita akan dapat meningkatkan dan berperan aktif dalam kegiatan posyandu. Tujuan umum penelitian ini adalah untuk mengetahui hubungan tingkat pendidikan dan pengetahuan ibu tentang gizi dengan tingkat kehadiran balita di posyandu kelurahan Tegalgede Kecamatan Sumbersari Kabupaten Jember.

Penelitian ini merupakan metode observasional analitik dengan pendekatan cross sectional. Populasi penelitian ini adalah seluruh ibu yang datang ke posyandu di kelurahan Tegalgede Kecamatan Sumbersari Kabupaten Jember yang sesuai dengan kriteria inklusi yang telah ditetapkan. Pengambilan sampel pada penelitian ini dengan metode purposive sampling yaitu 30 orang.

Hasil penelitian menunjukkan bahwa tidak ada hubungan antara tingkat pendidikan dengan tingkat kehadiran balita dan ada hubungan antara tingkat pengetahuan ibu tentang gizi dengan tingkat kehadiran balita di Posyandu Kelurahan Tegalgede Kecamatan Sumbersari Kabupaten Jember.
\end{abstract}

Kata kunci: Tingkat Pendidikan, Pengetahuan Ibu tentang gizi, kehadiran balita di posyandu.

\section{PENDAHULUAN}

Usaha Perbaikan Gizi Keluarga merupakan salah satu upaya untuk meningkatkan keadaan gizi masyarakat, yang sebagian kegiatannya dilaksanakan di posyandu. Usaha Perbaikan Gizi Keluarga ini dititikberatkan pada kegiatan penyuluhan gizi dengan menggunakan pesan - pesan gizi sederhana, pelayanan gizi, pemanfaatan lahan pekarangan, yang secara keseluruhan kegiatan tersebut dapat dilaksanakan oleh masyarakat sendiri.

Kegiatan yang dilakukan untuk menanggulangi masalah gizi antara lain dengan penimbangan secara berkala anak-anak dibawah lima tahun (Balita) yang pada hakekatnya merupakan perpaduan dari kegiatan pendidikan gizi, monitoring gizi, dan intervensi gizi melalui usaha-usaha Posyandu. Kegiatan ini bertolak dari usaha swadaya masyarakat dan sepenuhnya dilakukan oleh tenaga sukarela desa yang telah mendapat latihan dibawah pengawasan dari Puskesmas.

Usaha-usaha tersebut tidak akan berhasil tanpa didukung oleh usaha-usaha lain secara terpadu. Oleh karena itu usaha penanggulangan masalah gizi memerlukan kerjasama dan
Lebih dari itu, keberhasilan penanggulangan gizi sangat tergantung dari partisipasi aktif masyarakat yang ditandai oleh tingkat kehadiran $\mathrm{ibu}$ - ibu balita di posyandu.

Salah satu indikator keberhasilan posyandu dalam usaha perbaikan gizi adalah angka pencapaian program (N/S) yang tinggi. Pencapaian angka N/S ini perlu didukung oleh pencapaian angka partisipasi masyarakat (D/S ) yang tinggi pula. D/S menunjukkan perbandingan jumlah anak balita yang hadir dan ditimbang di posyandu dengan jumlah semua anak balita yang ada di suatu wilayah posyandu. D/S juga merupakan suatu rasio tingkat kehadiran anak balita di posyandu.

Pendidikan dan pengetahuan merupakan hal yang penting bagi manusia, yang dapat mengubah persepsi mengenai suatu hal. Pengetahuan, diartikan sebagai pengalaman yang kita alami. Pengalaman - pengalaman itu harus disusun dan diatur sedemikian rupa sehingga menjadi suatu keseluruhan yang berkaitan satu sama lain sebagai suatu gejala yang dapat diterangkan. Dengan pendidikan dan pengetahuan yang dimilikinya diharapkan seorang ibu akan dapat meningkatkan dan berperan aktif dalam 
Adhiningsih Yulianti, Hubungan Tingkat Pendidikan Dan Pengetahuan Ibu Tentang Gizi Dengan Tingkat Kehadiran Balita Di Posyandu Kelurahan Tegalgede Kecamatan Sumbersari Kabupaten Jember

kegiatan posyandu dan akan selalu berperilaku, bertindak dan bersikap untuk mendorong perilaku kesehatan

Dari uraian tersebut diatas dapat dirumuskan permasalahannya adalah:

"apakah ada hubungan antara tingkat pendidikan dan pengetahuan ibu tentang gizi dengan tingkat kehadiran balita di posyandu Kelurahan Tegalgede Kecamatan Sumbersari Kabupaten Jember ”

\section{METODE PENELITIAN}

\section{a. Jenis Penelitian}

Jenis penelitian yang digunakan pada penelitian ini adalah penelitian observasional analitik dengan menggunakan metode pendekatan cross sectional.

\section{b. Lokasi dan Waktu Penelitian}

Penelitian ini dilakukan di kelurahan Tegalgede Kecamatan Sumbersari Kabupaten Jember pada bulan Oktober 2012-Nopember 2012.

\section{c. Populasi dan Sampel}

Populasi adalah keseluruhan objek penelitian atau objek yang di teliti (Notoatmodjo, 2002).Populasi penelitian ini adalah seluruh ibu yang datang ke posyandu di kelurahan Tegalgede Kecamatan Sumbersari Kabupaten Jember.

Sampel adalah bagian yang diambil dari keseluruhan objek yang di teliti yang dianggap mewakili seluruh populasi (Notoatmodjo, 2002). Sampel dari penelitian ini adalah ibu yang mempunyai anak balitaPengambilan sampel dalam penelitian ini dengan menggunakan teknik Purpossive Sampling. Sampel yang akan diikutsertakan dalam penelitian adalah sampel yang memenuhi kriteria inklusi yaitu 30 orang responden.

\section{d. Teknik Pengumpulan Data}

Data primer didapatkan dari hasil pengisian angket pada responden atau subjek yang diteliti. Responden atau subjek yang diteliti adalah ibu yang mempunyai anak balita yang tinggal di Kelurahan Tegalgede Kecamatan Sumbersari Kabupaten Jember.

Data sekunder merupakan data yang didapatkan secara tidak langsung melalui Posyandudi kelurahan Tegalgede Kecamatan Sumbersari Kabupaten Jember.

Cara pengisian angket yang berisi tentang pernyataan yang berkaitan dengan pemenuhan kebutuhan nutrisi diisi sendiri oleh responden.Peneliti mendatangi rumah responden yang belum mengisi angket pada saat pelaksanaan posyandu balita, kemudian dilakukan pengumpulan data. Setelah data terkumpul dari semua responden, hasil di klasifikasikan oleh peneliti ke dalam kategori yang telah ditetapkan sebelumnya

\section{e. Pengolahan Data}

Data hasil pencatatan disajikan dalam bentuk tabel-tabel distributif yang kemudian dijabarkan secara deskriptif dan dianalisis dengan uji regresi linear ganda menggunakan SPSS 19.

\section{HASIL DAN PEMBAHASAN}

\section{a. Data Umum}

Data umum dalam penelitian ini menjelaskan tentang karakteristik responden yang terdiri dari umur ibu, pekerjaan ibu, umur balita dan jenis kelamin balitaKarakteristik responden berdasarkan umur dari ibu balita, pada umur 20-25 tahun 16 orang $(53,3 \%)$, umur 26-30 tahun 10 orang $(33,3 \%)$, dan umur 31-35 tahun 4 orang (13,3\%). Status pekerjaan responden yang tidak bekerja 15 orang $(50 \%)$ dan bekerja 15 orang (50\%). Karakteristik berdasarkan umur balita, pada umur 0-12 bulan 5 orang $(16,7 \%)$, umur $13-36$ bulan 18 orang $(60 \%)$ dan umur $37-60$ bulan 7 orang $(23,3 \%)$. Jenis kelamin balita sebagian besar adalah jenis kelamin perempuan yaitu sebanyak 17 orang $(56,3 \%)$ dan sisanya jenis kelamin laki-laki sebanyak 24 orang $(43,3 \%)$.

Karakteristik pekerjaan responden menyatakan bahwa responden yang bekerja dan tidak bekerja jumlahnya sama yaitu 15 orang $(50 \%$. Secara teori pekerjaan seseorang berhubungan dengan tingkat pendidikannya dan berhubungan pula dengan pengetahuannya tentang suatu hal. Menurut Mubarak (2007), lingkungan pekerjaan dapat menjadikan seseorang memperoleh pengalaman dan pengetahuan baik yang didapatkan secara langsung maupun secara tidak langsung.

\section{b. Data Univariat}

Analisa univariat dilakukan pada variabel tingkat pendidikan ibu, tingkat pengetahuan ibu tentang gizi dan tingkat kehadiran balita di Posyandu.

Penilaian tingkat pendidikan dikatagorikan menjadi SD, SLTP, SLTA dan Perguruan Tinggi.Penilaian tingkat pengetahuan ibu tentang gizi dikatagorikan menjadi tingkat pengetahuan baik, tingkat pengetahuan cukup, dan tingkat pengetahuan kurang.Penilaian tingkat kehadiran balita di Posyandu dikatagorikan menjadi tingkat kehadiran kurang dari 8 kali dan tingkat kehadiran lebih dari 8 kali.Analisa univariat 
data kategorik menggunakan distribusi dengan ukuran persentase.

Tingkat pendidikan responden terdiri dari SD 10 orang $(33,3 \%)$, SLTP 11 orang $(36,7 \%)$, SLTA 6 orang $(20 \%)$ dan Perguruan Tinggi 3 orang (10\%).Semakin tinggi tingkat pendidikan seseorang, maka semakin mudah seseorang menerima informasi baik dari orang lain maupun dari media massa. Pendidikan diharapkan mampu mengubah pola pikir seseorang. Mengutip dari teori yang ada dengan rendahnya tingkat pendidikan yang dimiliki seseorang maka kemungkinan penerimaan informasi akan lebih sedikit, dengan kata lain semakin tinggi tingkat pengetahuan seseorang maka semakin tinggi pula akses mereka untuk memperoleh pengetahuan tentang sesuatu sehingga lebih mudah untuk memperoleh informasi dan akan semakin banyak pengetahuan yang dimiliki

Tingkat pengetahuan ibu tentang gizi sebagian besar mempunyai tingkat pengetahuan yang baik sebanyak 17 orang $(56,7 \%)$ dan 13 orang $(43,3 \%)$ mempunyai tingkat pengetahuan cukup.Pengkategorian tingkatan pengetahuan pada penelitian ini dapat dilihat bahwa jumlah responden yang memiliki tingkat pengetahuan baik dan cukup hampir seimbang.Responden yang masuk dalam kategori pengetahuan baik berkaitan erat dengan karakteristik masing-masing responden yang mempengaruhi pengetahuan mereka misalnya tingkat pendidikan.Ibu yang yang berpendidikan terakhir SLTP pengetahuannya lebih baik dibandingkan dengan ibu yang pendidikan terakhirnya SD, sesuai dengan jumlah skor pada pengisian angket. Semakin tinggi tingkat pendidikan seseorang maka semakin tinggi pula kemampuan seseorang untuk menyerap dan mengolah pengetahuan baik dalam pendidikan informal dan non formal

Tingkat kehadiran balita di Posyandu yang lebih dari 8 kali sebanyak 17 orang $(56,7 \%)$ dan yang kurang dari 8 kali sebanyak 13 orang $(43,3 \%)$.Hal ini menunjukkan bahwa partisipasi ibu balita yang datang ke Posyandu sangat baik.Tingkat kehadiran anak balita di posyandu dapat dipengaruhi oleh beberapa faktor antara lain aktifitas kader, kelengkapan sarana, tingkat pengetahuan ibu balita tentang posyandu, keaktifan petugas pembina dan tingkat pendidikan.

Tingkat kehadiran balita yang kurang dari 8 kali di Posyandu mungkin disebabkan oleh beberapa alasan, yaituibu terlalu sibuk atau tidak bisa mengelola waktu mereka pada pekerjaan rumah tangga, kurangnya penyebaran informasi tentang pentingnya Posyandu, kurangnya dukungan keluarga dan kondisi ekonomi

\section{c. Data Bivariat}

Data bivariat menjelaskan tentang hubungan tingkat pendidikan dan tingkat pengetahuan ibu tentang gizi dengan tingkat kehadiran balita di Posyandu Kelurahan Tegalgede Kecamatan Sumbersari Kabupaten Jember.

1. Hubungan Tingkat Pendidikan dengan Tingkat Kehadiran Balita di Posyandu Kelurahan Tegalgede Kecamatan Sumbersari Kabupaten Jember

Nilai $\mathrm{p}$ menunjukkan bahwa $\mathrm{p}>\alpha$ $(0.961>0.05)$ dapat disimpulkan tidak ada hubungan antara tingkat pendidikan dan tingkat kehadiran balita di Posyandu Kelurahan Tegalgede Kecamatan Sumbersari Kabupaten Jember.

Kekuatan korelasi dilihat melalui nilai $r$ yaitu sebesar 0,009 yang memiliki arti bahwa kekuatan hubungan antar variabel adalah tidak ada hubungan.Arah korelasi pada hasil penelitian ini adalah tidak ada hubungan sehingga tingkat pendidikan tidak berhubungan dengan tingkat kehadiran balita di Posyandu.Hal ini tidak sesuai dengan teori yang ada yang menyatakan bahwa pendidikan akan mempengaruhi tingkat kehadiran di Posyandu. Hasil penelitian ini berbeda karena faktor-faktor yang mempengaruhi tingkat kehadiran balita diposyandu tidak hanya pendidikan tetapi ada faktorfaktor lain yang mempengaruhinya seperti aktifitas kader, kelengkapan sarana, tingkat pengetahuan ibu balita tentang posyandu, dan keaktifan petugas pembina.

2. Hubungan Tingkat Pengetahuan Ibu tentang Gizi dengan Tingkat Kehadiran Balita di Posyandu Kelurahan Tegalgede Kecamatan Sumbersari Kabupaten Jember

Nilai $p$ pada tabel 5.5 menunjukkan bahwa $\mathrm{p}<\alpha(0,001<0,05)$ dapat disimpulkan ada hubungan antara tingkat pengetahuan ibu tentang gizi dengan tingkat kehadiran balita di Posyandu Kelurahan Tegalgede Kecamatan Sumbersari Kabupaten Jember. Kekuatan korelasi dilihat melalui nilai $r$ yaitu sebesar 0,592 yang memiliki arti bahwa kekuatan hubungan antar variabel adalah kuat. Arah korelasi pada hasil 
Adhiningsih Yulianti, Hubungan Tingkat Pendidikan Dan Pengetahuan Ibu Tentang Gizi Dengan Tingkat Kehadiran Balita Di Posyandu Kelurahan Tegalgede Kecamatan Sumbersari Kabupaten Jember

penelitian ini adalah positif (+) sehingga semakin baik tingkat pengetahuan ibu tentang gizi maka semakin baik tingkat kehadiran balita di Posyandu. Pengetahuan dalam Notoatmodjo (2007) adalah hasil 'tahu' dan ini terjadi setelah orang melakukan penginderaan terhadap suatu objek tertentu.Pengetahuan atau kognitif merupakan domain yang sangat penting untuk terbentuknya tindakan seseorang (overt behavior). Pengetahuan ibu balita yang baik mengenai gizi tentunya akan terkait dengan cakupan penimbangan balita di Posyandu

\section{KESIMPULAN DAN SARAN}

Kesimpulan

1. Tingkat pengetahuan ibu balita tentang gizi adalah baik.

2. Mayoritas tingkat pendidikan ibu balita adalah SD.

3. Tidak ada hubungan antara tingkat pendidikan dengan tingkat kehadiran balita di Posyandu kelurahan Tegalgede Kecamatan Sumbersari Kabupaten Jember.

4. Ada hubungan antara tingkat pengetahuan ibu tentang gizi dengan tingkat kehadiran balita di Posyandu kelurahan Tegalgede Kecamatan Sumbersari Kabupaten Jember

Saran

1. Perlu dilakukan penyuluhan-penyuluhan terkait gizi seimbang di posyandu.

2. Perlu dilakukan penelitian lanjutan terkait hubungan tingkat pengetahuan ibu tentang gizi dengan status gizi balita.

\section{DAFTAR PUSTAKA}

Almatzier. Sunita. 2002. Prinsip Dasar Ilmu Gizi. Jakarta: Gramedia Pustaka Utama.

Arikunto, Suharsini. 2002. Prosedur Penelitian : Suatu Pendekatan Praktek. Jakarta : Asdi Maha Satya

Asdhany, C., dan Kartini, A. 2012. Hubungan Tingkat Partisipasi Ibu dalam Kegiatan Posyandu dengan Status Gizi Anak Balita (Studi di Kelurahan Cangkiran Kecamatan Mijen Kota Semarang). Journal of Nutrition College (Vol 1, No 1:38-55). Serial online: http://e-journals1.undip.ac.id.
Departemen Kesehatan. 2007. Keputusan Menteri Kesehatan Republik Indonesia Nomor 747/Menkes/SK/VI/2007 tentang Pedoman Operasional Keluarga Sadar Gizi di Desa Siaga. Jakarta: Direktorat Jenderal Bina Kesehatan Masyarakat, Direktorat Bina Gizi Masyarakat.

Departemen Kesehatan. 2007. Pedoman Strategi KIE Keluarga Sadar Gizi (KADARZI). Jakarta:Direktorat Jenderal Bina Kesehatan Masyarakat dan Direktorat Bina Gizi Masyarakat.

Kementerian Kesehatan Republik Indonesia. 2010.Rencana Aksi Pembinaan Gizi Masyarakat 2010-2014. Jakarta:Direktorat Jenderal Bina Kesehatan Masyarakat.

Kementerian Kesehatan Republik Indonesia. 2011.Pedoman Umum Pengelolaan Posyandu. Jakarta:Kementerian Kesehatan Republik Indonesia Sekretariat Jenderal.

Lestari, P., dkk. 2012. Hubungan Tingkat Kehadiran Balita di Posyandu dengan Hasil Pengukuran Antropometri Balita di Posyandu Balitaku Sayang RW 04 Kelurahan Jangli Kecamatan Tembalang Kota Semarang. Jurnal Gizi Universitas Muhamadiyah Semarang (Vol 1, No 1). Serial Online http://jurnal.unimus.ac.id.

Nazir, M. 2003. Metode Penelitian. Bogor: Ghalia Indonesia.

Notoatmodjo, Soekidjo. 2002. Metodologi Penelitian Kesehatan. Edisi Revisi. Jakarta: Rineka Cipta.

Notoatmodjo, Soekidjo. 2003. Pendidikan dan Perilaku Kesehatan. Jakarta: Rineka Cipta.

Notoatmodjo, Soekidjo. 2005. Metodologi Penelitian Kesehatan. Jakarta: Rineka Cipta.

Notoatmojo, Soekidjo. 2010. Metode Penelitian Kesehatan. Jakarta: Rineka Cipta.
Nursalam. 2003.
Konsep dan Penerapan
Metodologi Penelitian dalam
Keperawatan. Jakarta: Salemba Medika. 